\section{The Role of Islamic Journalists in Coinsuring the Community towards the Provision of Hajj in 2021 in Covid-19 Pandemic Situation}

\author{
M. Yoserizal Saragih \\ Universitas Islam Negeri Sumatera Utara, Indonesia \\ yosesaragih77@gmail.com
}

\begin{abstract}
This paper reviews the role of Islamic journalism in convincing the public to announce the 2021 Hajj in the midst of Covid-19, which is currently confusing the public. With the aim that the public can understand what is happening in the midst of the current Covid-19 polemic. The methodology used is literature study, because the source of the research is written data that is relevant to the topic to be discussed. This paper is a descriptive analysis that aims to describe, inventory, and analyze the actual conditions regarding the role of Islamic journalism in convincing the public to report the Hajj in 2021 in a systematic, factual and accurate manner. With the results of the discussion that journalism is not only recording, conveying and disseminating information, but journalism also has an important role to the community in reporting. The role of Islamic journalism in convincing the public to report the Hajj in 2021 amid Covid-19, Islamic journalism is known as an educator (muaddib), information straightener (musaddid), reformer (mujaddid), unifier (muwahid), and warrior (mujahid). To carry out this role, Islamic journalism has the characteristic that every information in a news report must be owned by the Prophet such as shidiq (truth), amanah (trusted), tabligh (deliver), and fathonah (intelligent).
\end{abstract}

Keywords

the role of islamic journalism; convincing the community; reporting on the Hajj in the midst of covid-19

\section{Introduction}

Hajj is the 5th pillar of Islam. Going for Hajj to Batullah Mecca is an obligation for Muslims who are physically and financially capable. Going for Hajj is obligatory once in a lifetime. Allah says in Surah Ali-Imran: 97, which means: "Performing Hajj is a human obligation to Allah, namely (for) those who are able to travel to the Baitullah. Whoever denies (the obligation of Hajj), then indeed Allah is Rich (does not need anything) of the universe."

Stories about the pilgrimage, especially in the midst of the current Covid-19 pandemic, there are many reports in various media regarding the pilgrimage in 2021 which are very hotly discussed in various media. Especially regarding the confusing quota for the departure of the Hajj pilgrimage in 2021, then the reports on Arabic permits/foreign exchange for Indonesian Hajj pilgrims, as well as many more reports about the 2021 Hajj pilgrimage that makes people confused about the content of the news information in the media. This is also not inferior to the soaring Covid-19 cases in Indonesia.

The government, in this case the Ministry of Religion, has canceled the departure of the congregation hajj Indonesia in 2021. The cause is of course the Covid-19 virus pandemic. Previously, the Government of the Republic of Indonesia on June 3, 2021 had announced the cancellation of the departure of pilgrims for the Hajj pilgrimage in 1422 
$\mathrm{H} / 2021 \mathrm{AD}$. This bitter decision was taken in the midst of the high and worrying situation of the spread of the Covid-19 pandemic. The safety and security of the Hajj pilgrims is a major consideration for the Government of Indonesia. The Kingdom of Saudi Arabia on June 12, 2021/2 Zulkaidah $1422 \mathrm{H}$ has also announced its decision that the Hajj 1442 $\mathrm{H} / 2021$ AD is set only for Saudi citizens and residents of other countries who have been in the country. Due to the Covid-19 Pandemic situation, the quota for Hajj in 2021 is only 60 thousand people for prospective pilgrims who are already living in Saudi Arabia.

Based on the news of the pilgrimage, which became a polemic in the eyes of the public, some Indonesians viewed that the cancellation of the departure of the Indonesian Hajj pilgrims in 2021 was just a trick. There are even some people who have a negative view of the news of the cancellation of the 2021 Hajj departure.

Behind the news of the 2021 hajj, journalism has a role in conveying important news for the public to know, for example about news about the discourse of canceling the hajj in 2021, as well as the dangers of the impact of Covid-19 which is spreading, because in Law no. 8 of 2019 concerning the implementation of Hajj and Umrah, there is a trilogy of coaching, service, and protection for Hajj and Umrah pilgrims. Protection can be understood to include travel conditions and while in the holy land that must be safe and secure. Meanwhile, the uncontrolled Covid-19 pandemic poses a threat to health, security, and life safety. The government has an obligation to protect the safety of citizens, both at home and abroad.

Based on the polemic on reporting on the pilgrimage, the role of journalism is very necessary, especially Islamic journalism because Islamic journalism is reporting or reporting on various matters that are loaded with content and socialization of Islamic values. The role of Islamic journalism in reporting is very important because in the role of Islamic journalism it contains elements of as a unifier (muwahid) because Islamic journalism is able tobecome a bridge to unite Muslims. So that with the case of various reports in various media about the pilgrimage in 2021 in the midst of the Covid-19 pandemic, hopefully the role of Islamic journalism will be able to dampen the community. So, with this case, the author wants to study or write an article in the form of a scientific paper with the title of the role of Islamic journalism in increasing public confidence in the news of the 2021 Hajj in the midst of the Covid-19 pandemic.

\section{Review of Literature}

\subsection{The Role of Islamic Journalism}

Role is a form of behavior expected of a person in certain social situations. If what is meant by a role is the behavior expected of a person in a certain status, then role behavior is the actual behavior of the person who performs the role, essentially the role can also be formulated as a series of certain behaviors caused by a certain position. Meanwhile, journalism is collecting, processing and disseminating news to the widest possible audience as quickly as possible. The term journalism at this time, may be familiar to the ears. In the Big Indonesian Dictionary it is stated that journalism is the work of collecting, writing, editing and publishing news in newspapers and so on, which relates to journalism and newspapers. Seeing the above understanding, the first point provides an understanding because the first point provides in-depth details starting from the process of gathering news to publishing in newspapers (print media), although in this current era, not only print media but also electronic media are becoming media for journalistic activities. 
Journalism adheres to the principles of speed. Meaning, speed in which information can be immediately accepted by journalists and quickly disseminated through the mass media. Free reporters covering an event or to obtain news is influenced by the ability of journalists. The ability owned by the reporter is obtained through the knowledge and experience possessed by the reporter. (Saragih, 2018). Islam in general is the shari'ah of Allah swt which was revealed to all prophets and apostles. In particular, Islam is a religion that was revealed by Allah SWT to the Prophet Muhammad, the cover of the Shari'a of the previous prophets and apostles. So, the role of Islamic journalism is a series of certain behaviors caused by a journalist (journalist) who collects, manages, writes, edits data, so as to produce information or news, whose information is about daily events, periodically using mass media facilities there are based on Islamic laws that have been set based on the Qur'an and hadith.

\subsection{Convincing the Community}

Meanconvincingin KBBI are: witness for yourself to be sure; ensure. Convincing means to make people believe and believe in what we are talking about or what we are explaining. Meanwhile, society isUnits or groups that have relationships and some similarities such as attitudes, traditions, feelings and culture that form an order. According to Horton in M. Zaini Hasan et al., community is a group of humans who are relatively independent, who live together for a relatively long time inhabiting a certain area, have a relatively long culture, and carry out activities for a long time in the group. Furthermore, Horton in M. Zaini Hasan et al., said that society is a group of people who live in a certain area, which has a special and interdependent division of labor, and has a socio-cultural system that regulates the activities of its members, which has a specific function. awareness of oneness and a sense of belonging, and the ability to act in an orderly manner. So, a group of people who have lived long enough in a certain area and work together, have a division of labor so that they can organize and have the same habits, traditions, attitudes and feelings of unity to achieve a certain goal. Based on the above definition, the purpose of convincing the community in this study is to ensure or make people believe and believe in what we are talking about to a group of people who live in their daily habits.

\subsection{News of Hajj in 2021}

Reporting in the dictionary is (1) the process, method, act of reporting (reporting, announcing); (2) news, announcements. The definition of news according to William S. Maulsby is a true and impartial narrative of facts that have important meaning and have just happened, which can attract the attention of readers of newspapers that contain it. Indirectly in this sense the mass media must act in accordance with the rules of news journalism. The media must be neutral without any frills of a political interest, or being infiltrated by the political elite in power.

According to Emery, Ault, Age, the press has a function to provide objective information to readers about what can make people, country and world happy. In addition, it also provides comments through its editorials in order to obtain guidance on developments that are currently of concern and also provides information about needed items through advertisements or advertisements. Hajj is the 5th pillar of Islam. Going for Hajj to Batullah Mecca is an obligation for Muslims who are physically and financially capable. So, the news of the pilgrimage referred to in this study is news or facts about the departure of the pilgrims in the midst of the Covid-19 pandemic. 


\section{Results and Discussion}

\subsection{News of the 2021 Hajj Worship Amid the Covid-19 Pandemic}

The news of the 2021 hajj pilgrimage in the midst of the Covid-19 pandemic in various media was widely discussed, there were several mass media reporting about the 2021 hajj in the midst of the Covid-19 pandemic. Some reports in the media such as the news reported by CNN Indonesia media that "The Government"Saudi Arabiaofficially announced the implementation of worshiphajjyear 2021". The Indonesian Ambassador to Saudi Arabia Agus Maftuh Abegebriel said the 2021 Hajj pilgrimage was only limited to domestic pilgrims, both local citizens and expatriates who were in the Kingdom's territory. The number of worshipers is also limited to only 60 thousand. The maximum number is 60 thousand worshipers, aged 18 to 65," Agus said in a short message to CNNIndonesia.com, Saturday (12/6). The news reported by CNN Indonesia media that the 2021 Hajj pilgrimage will still exist, however, it is only intended for Arab citizens, and the number of pilgrims is limited in accordance with the procedures established by the government of the kingdom of Saudi Arabia.

The news of the 2021 Hajj pilgrimage was also reported by the Kompas.com media. This is the same as the news on CNN Indonesia media that the decision was taken taking into account the development of the Covid-19 virus pandemic that has emerged throughout the world and the emergence of new virus variants. Quoted from Arab News, Saudi Arabia's announcement regarding the restrictions on the 2021 Hajj pilgrimage emphasizes that those who will depart for Hajj must be free from any chronic diseases. In addition, they must be between 18 and 65 years old and have been vaccinated against the virus according to the vaccination steps implemented by the kingdom of Saudi Arabia.

News of the pilgrimage in 2021 in the midst of Covid-19 is currently also reported via Liputan6 news. The news about the Hajj covered by Liputan6 provides colorful information about the Hajj in 2021, there are several reports such as:the quota is only 60 thousand, for Hajj candidates in Saudi Arabia the list goes through 450 thousand. Then the news Safety in the midst of Covid-19 is the reason Saudi Arabia imposes restrictions on Hajj 2021. And, Saudi Arabiafor the second year prohibiting the arrival of the congregationHajjfrom other countries, and limiting the organization of worship to only citizens and residents in the country in response to the corona virus pandemicCovid-19.

News about the next pilgrimage is also found in Kontan.co.id media, in the news that the government has decided to cancel the departure of the 2021 hajj pilgrimage. This is stated in the Minister of Religion Decree number 660 of 2021 concerning the cancellation of the departure of hajj pilgrims in the implementation of the hajj pilgrimage this year. 2021. The decision was taken after the government made preparations since December 24, 2020 by forming a hajj crisis management team during the Covid-19 pandemic. Then, carry out diplomacy with the Saudi Arabian government and prepare everything related to the implementation of Hajj during the pandemic for domestic services.

According to a statement from the Indonesian Minister of Religion M. Yaqut that the Covid-19 pandemic has not yet passed. Although the handling of Covid-19 in Indonesia has started to look good, in other parts of the world the Covid-19 pandemic is still not well controlled. Yaqut said the cancellation of the pilgrimage was carried out with a number of considerations. First, that performing the pilgrimage is obligatory for Muslims who are economically and physically capable and ensure the health, safety and security of the pilgrims while they are at the embarkation or dibercation, on the way, and in Saudi Arabia. Second, the health, safety and security of pilgrims are threatened by the Covid-19 
pandemic and its new variants that have hit almost all countries in the world. Including Indonesia and Saudi Arabia. Third, the government is responsible for safeguarding and protecting Indonesian citizens both at home and abroad through efforts to overcome the Covid-19 pandemic. Fourth, in the teachings of Islam, protecting the soul is one of the efforts of the five teachings, in addition to protecting religion, reason, offspring and assets that must be used as the main basis for consideration in the determination of laws or policies by the government in order to realize the benefit of the community. Fifth, the government of Saudi Arabia has not opened access to services for the implementation of the Hajj pilgrimage in 2021 and the Indonesian government needs sufficient time to prepare services for pilgrims.

Regarding the news about the pilgrimage in 2021 in the midst of the current Covid19 pandemic, which has drawn protests from the public that some people view that the cancellation of the pilgrimage has run out of funds, there are even people who think that the cancellation of the pilgrimage in 2021 because the pilgrimage will be abolished, then there are also people who think that the cancellation of the pilgrimage is due to a lack of communication between the governments of the two countries. And many more negative responses in the community regarding this news.

Based on some of the news regarding the pilgrimage in 2021 that the author quoted above, there are also various reports in various media such as TV, Social Media, print media and others as we see today, sometimes the information is confusing so that people find it difficult to understand the contents of the news. delivered so as to cause an unsatisfactory response to the community. therefore, journalism has an important role in convincing the public to be able to pay close attention to the news delivered in various media. Especially the role of Islamic journalism because Islamic journalism is a means that can unite the ummah.

\subsection{Islamic Journalism Role Theory}

Role Theory is a theory which is a combination of various theories, orientations, and disciplines. The term "role" is taken from the world of theater. In theater, an actor must play a certain character and in his position as a character he is expected to behave in a certain way. Role means behavior, act. In the big Indonesian dictionary, role is a set of behaviors that are expected to be possessed by people who are domiciled in society. Role theory is a point of view insociologyandsocial psychologywho assume that most daily activities are played by socially defined categories (eg mother, manager, teacher). Each social role is a set of rights, obligations, expectations, norms, and behavior of a person that must be faced and fulfilled. This model is based on the observation that people act in predictable ways, and that a person's behavior depends on the context, based on social position and other factors.

Literally, journalism comes from the word 'journal' or diary. Journalism means the broadcasting of diaries, news or journalism matters. Dja'far $\mathrm{H}$ Assegaf detailed the definition of journalism as an activity that aims to convey messages or news to the public, through media channels. The media used can be in the form of print media, electronic media or the internet. The press and journalism are two things that are related, but have different meanings. Journalism is a form of work, or the work of journalists. While the press is a medium used by journalists to convey the results of their journalistic work.

JournalismIslam is the process of covering,write, and spread news about religion and Muslims with the aim of building positive perceptions and images about Islam and Muslims. Islamic Journalism is a branch of journalism that focuses on the religious field. 
This type of journalist is certainly based on a religious perspectiveespecially Islam. The press and journalism are two things that are related, but have different meanings. Journalism is a form of work, or the work of journalists. While the press is a medium used by journalists to convey the results of their journalistic work. Islamic journalism also plays an important role in disseminating messages or news to the public. Generally The following are the 13 roles of journalism in society:

a. As a reform agent

b. Entertainer

c. Social control tool

d. Community educator

e. Information Giver

f. Broaden the horizons of thought

g. Focusing

h. Cultivating aspirations

i. Creating a constructive atmosphere

j. As a bridge

$\mathrm{k}$. Able to recognize social norms

1. Able to grow appetite

m. Being able to change a weak attitude into a stronger attitude.

Meanwhile, from an Islamic perspective, according to Romli, there are five roles of Islamic journalism, namely:

1. As an educator (muaddib), namely carrying out Islamic education functions.

2. Islamic journalists function as information straighteners (musaddid).

3. Journalists must be present as reformers (mujaddid), namely carriers and reformers.

4. The task of Islamic journalism must be unifying (muwahid), namely a bridge to unite Muslims.

5. Islamic journalists function as fighters (mujahid), namely fighting for the truth.

\subsection{The Role of Islamic Journalism in Convincing the Public against a Report}

Islamic journalism is one of the answers to various challenges faced by Muslims. Therefore he must try to make journalism always in accordance with Islamic values as "ideology". Islamic journalists with their ideology will encourage the emergence of passion, enthusiasm, defend the interests of Islam and its people, also socialize Islamic values, as well as counter and filter the rapid flow of negative information from anti-Islam. It can also be said that Islamic journalism is defined as "the process of reporting or reporting on various matters that are loaded with Islamic values". Islamic journalism can be said as crusade journalism, namely journalism that fights for certain values, namely the values of Islam itself. Islamic journalism carries out the mission of 'amar ma'ruf nahi munkar. Islamic journalistic reporting itself through its mass media which functions as a channel of information from the people to the government and vice versa.

Based on the literacy study of this paper, the role of Islamic journalism is very important in convincing the public of news, especially about the pilgrimage in the midst of the Covid-19 pandemic. The importance of the role of Islamic journalism in convincing the public is very important because Islamic journalism is a process of reporting or reporting on various matters containing Islamic values. Related to the theory of the role of Islamic journalists, it is very influential on a news report to convince the public, because people really need information about the development of something that has happened, or has not, and will happen. As we know that in various media, almost on average they talk about the 
2021 Hajj pilgrimage in the midst of the Covid-19 pandemic where some people still give negative responses, so for that,conveying messages or news to the public is very important. So, the role of Islamic journalists in the world of journalism can be seen in the character and the central mission to be addressed, namely amar ma'ruf nahi munkar. This means that the characteristic of Islamic journalists is to disseminate information about the commands and prohibitions of Allah SWT. He advised to give (message) and try hard to influence the communicant (audience), so that they can behave in accordance with Islamic teachings. The role of Islamic journalism in convincing the public about the news of the 2021 Hajj in the midst of Covid-19 is as follows:

1. first, journalism must be critical of the external environment and be able to filter information from the West which sometimes plants a criminal bias against Islam.

2. Second, Islamic journalism must be able to become a translator and frontier spirit for renewal and contemporary creative ideas. Here Islam needs to be oriented forward in order to be able to talk about various social problems today and in the future.

3. Third, Islamic journalism should be able to carry out the socialization process as an effort to maintain and develop Islamic intellectual treasures.

4. Fourth, Islamic journalism must be able to unite groups of people while providing readiness to be open to differences of understanding.

According to Jalaluddin Rakhmat quoted by Asep Syamsul M. Romli, Islamic journalism must act as educators (muaddib), straighteners of information (musaddid), reformers (mujaddid), unifiers (muwahid), and as fighters (mujahid).

1. As an educator (muaddib)

That is, carrying out the function of Islamic education. He must master the teachings of Islam more than the average audience of readers. Through the mass media, he educates Muslims to carry out Allah's commands and stay away from His prohibitions. He bears the noble task of preventing Muslims from behaving in ways that deviate from Islamic law, as well as protecting them from the bad influence of anti-Islamic non-Islamic mass media.

The role of Islamic journalism as an educator (muaddib), can be applied to Islamic journalism in convincing the public about the news of the 2021 Hajj in the midst of Covid19. Regarding the news, Islamic journalism as an educator (muaddib) is given to the community in the form of education or invitations and explanations for news that is detrimental to the community's surroundings.

2. As information straightener (musaddid)

Islamic journalists play an active role in modern communication media. As in the Qur'an Allah SWT says:

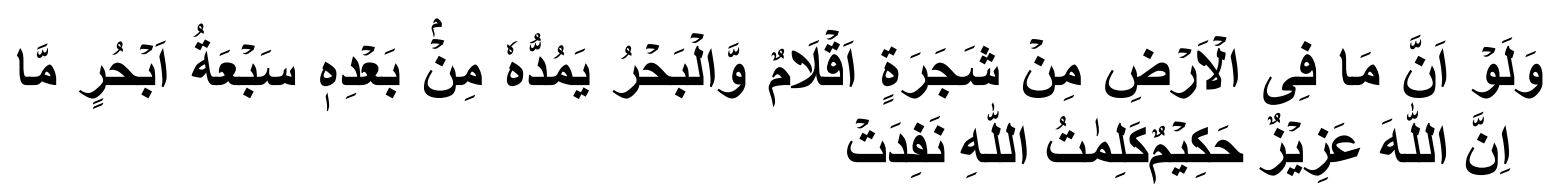

Meaning: "And if the trees of the earth were pens and the seas (ink) were added to it seven seas (again) after it (dry), surely Allah's words would not be exhausted. Verily Allah is Mighty and Wise."

This verse explains that Islam already recognizes the importance of writing in this life. Because writing is very beneficial in human life in various aspects of life. Writing can also be useful for others around us. For example, our knowledge or understanding of something that is considered necessary for others to know. Of course we can not convey it 
to people one by one directly. By writing it down, then printing or reproducing it, then sharing it with others will make it easier to disseminate the information.

The role of journalism is to be an agent of information to the public. Currently all the information we need, can be accessed through the mass media. There are no longer significant obstacles to all events that occur in various parts of the world, including Indonesia. The role of journalism in covering these important events makes it easier for the public to get information. Whereas in many cases, currently there is still information that the public cannot understand in detail, especially information on the news of the 2021 Hajj pilgrimage.

The role of journalists as information straighteners (musaddid) especially in reporting the 2021 Hajj in the midst of Covid-19,Musaddid's role feels relevance and urgency considering that information about Islam and its people that comes from the Western press is usually biased (deviant, one-sided) and distorted, manipulative, aka full of engineering to corner Islam that he does not like. Here, Islamic journalism is required to change the public's perception of the news in the media. Especially the news that is the product of anti-Islamic Western press propaganda.

3. As a reformer (mujaddid)

Islamic journalism is also known as reformer (mujaddid), it means that every news that is in the media that is not satisfied for the community, Islamic journalists have a role in this, Islamic journalists can be the spokespersons for reformers, who call on Muslims to uphold the Qur'an and Sunnah, purify their understanding of Islam and its practice (cleaning it of heresy, superstition, superstition, and foreign non-Islamicisms). , and apply it in all aspects of people's lives. And Islamic journalists can be a bridge for the community to problems or news that are confusing the public, such as the news of the 2021 Hajj in the midst of the current Covid-19. things like this, Islamic journalism has an important role as areformer (mujaddid) for the community, as well ascan carry out the socialization process as an effort to maintain and develop Islamic intellectual treasures.

4. As a unifier (muwahid)

The role of Islamic journalism as a unifier (muwahid). Islamic journalism is a bridge that unites Muslims. Islamic journalism is able to apply a journalistic code of ethics in the form of impartiality (not taking sides with certain groups) and is able to present two sides of view for every information. Islamic journalism is able to throw away sectarian attitudes. So, with the news about the pilgrimage in 2021 in the midst of the current Covid-19, which makes some people have a negative perception, therefore, the role of journalism as a unifier(muwahid), can increase public confidence or trust in the cancellation of the pilgrimage in 2021 amid Covid-19 only for health reasons because health is very important in the implementation of the pilgrimage. Based on the role of Islamic journalismas educators (muaddib), straighteners of information (musaddid), and reformers (mujaddid), the role of journalism as unifying (muwahid) has an important role.

5. As a fighter (mujahid)

Islamic journalists are fighters (mujahid), including fighting for misunderstandings over the newsabout the pilgrimage in 2021 in the midst of the current Covid-19 to the community. As defenders of Islam, through the media, Islamic journalists try to form public opinion that encourages the enforcement of Islamic values. So, with the role of journalism as a fighter (mujahid), this role can encourage the public to report the cancellation of the 2021 hajj amidst Covid-19. The confusion of news that the public can now quell their anger over this information. Because Islamic journalists can function 
aseducator (muaddib), straightener of information (musaddid), reformer (mujaddid), and unifier (muwahid).

Related to the role of Islamic journalism in convincing the public about the news of the 2021 Hajj in the midst of Covid-19. The thing that needs to be emphasized is that the nature of every information in a news report must be that of the ProphetShidiq, Amanah, Tabligh, and Fathonah. Shidiq means true, that is, informing what is right and defending and upholding the truth. The standard of truth is, of course, conformity with Islamic teachings (the Qur'an and As-Sunnah). Amanah means trustworthy, trustworthy, so it is not permissible to lie, manipulate or distort facts, and so on. Tabligh means to convey, that is to inform the truth, not to hide it. While Fathonah means intelligent and broad-minded. Islamic journalists are required to be able to analyze and read the situation, including reading what the people/society need.

\section{Conclusion}

Based on the description above, it can be concluded that journalism is not only recording, conveying and disseminating information, but rather the art or skill of delivering news. The role of Islamic journalism in convincing the public to report the Hajj in 2021 amidst Covid-19, Islamic journalism is known asas educators (muaddib), straighteners of information (musaddid), reformers (mujaddid), unifiers (muwahid), and fighters(mujahid). To carry out this role, Islamic journalism has the characteristic that every information in a news report must be owned by the Prophet, such as: shidiq (truth), amanah (trusted), tabligh (deliver), and fathonah (intelligent).

In addition, journalism also has other roles, namely, as a reform agent, entertainment provider, social control tool, public educator, information provider, broadening the horizons of thought, focusing attention, fostering aspirations, creating a constructive atmosphere, as a bridge, being able to recognize social norms., able to grow appetite, as well asable to change a weak attitude into a stronger attitude.

\section{References}

Aliyah Nur'aini Hanum. (2012). Studies Falsafah Jurnalisme Islami, Jurnal KhatulistiwaJournal Of Islamic, Volume 2 Nomor 2 September.

AL-Khoir. (2021). https://www.alkhoirmoslemwear.com/pengertian-islam-menurutbahasa-arab-quran-hadits-dan-ulama/ diakses pada: 19 Juni.

Asep Syamsul M Romli. (2003). Jurnalistik Dakwah: Visi dan Misi Dakwah Bil Qolam, Bandung: Rosdakarya.

Asep Syamsul M. Romli. (2003). Jurnalistik Dakwah: Visi dan Misi Dakwah Bil Qolam, Bandung: Rosdakarya.

CNN Indonesia. (2021). https://www.cnnindonesia.com/internasional/20210612174253120-653546/arab-saudi-resmi-gelar-ibadah-haji-2021, diakses pada: 20 Juni.

Departemen Agama RI. (2009). Alqur'an dan Tafsirnya, Jilid 1, Jakarta: PT. Karya Toha Putra.

Departemen Pendidikan Nasional. (2003). Kamus Besar Bahasa Indonesia, Cet. III, Jakarta: Balai Pustaka.

Edwin Emery, Philip H Ault K Warren. (1960). Introduction To Mass Communications, New York: Longman. 
Haidir Fitra Siagian. (2014). Peran dan Tanggung Jawab Jurnalis Muslim, Makassar: Kampus UKM Bangi.

Hikmat Kususmaningrat \& Purnama Kusumaningrat. (2009). Jurnalistik: Teori dan Praktik, Bandung: PT Remaja RosdaKarya.

https://pakarkomunikasi.com/peran-jurnalistik-dalam-masyarakat, diakses pada: 11 Maret 2021.

Jailani. (2014). Fikih Jurnalistik, Perspektif Syariat Islam Di Aceh, Banda Aceh: SEARFIQH Banda Aceh.

M. Fuad Nasar. (2021). Ibadah Haji dan Pandemi Covid 19, https://kastara.id/18/06/2021/ibadah-haji-dan-pandemi-covid-19/ diakses pada: 18 Juni.

M. Fuad Nasar. (2021). Ibadah Haji dan Pandemi Covid 19, https://kemenag.go.id/read/ibadah-haji-dan-pandemi-covid-19, diakses pada: 18 Juni.

M. Zaini Hasan et al. (1996). Pengantar Ilmu Sosial, Departemen Pendidikan dan Kebudayaan, Jakarta: Jalan Pintu.

Menteri Agama RI Yaqut Cholil Qoumas pada 3 Juni 2021, diakses di Media Redaksi.

Muis. (1999). Jurnalistik Hukum Dan Komunikasi Massa; Menjangkau Era Cybercomunikation Milenium Ketiga, Jakarta: PT. Dharu Anuttama.

Nur Rohmi Aida. (2021). Arab Saudi Umumkan Pelaksanaan Ibadah Haji 2021, https://www.kompas.com/tren/read/2021/06/12/193900565/arab-saudi-umumkanpelaksanaan-ibadah-haji-2021-ini-perinciannya-, diakses pada: 20 Juni.

Riyadh. (2021). https://www.liputan6.com/global/read/4580492/arab-saudi-larang-jemaahhaji-2021-dari-luar-negeri-kuota-khusus-orang-setempat, diakses pada: 20 Juni.

Romeltea. (2021). https://romeltea.com/jurnalistik-islami-ideologi-media-dakwah/, diakses pada: 18 Juni.

Romeltea. (2021). https://romeltea.com/jurnalistik-islami-ideologi-media-dakwah/, diakses pada: 20 Juni.

Saragih, M. (2018). Some Characteristics of Islamic Journalism Based on Al Quran. Budapest International Research and Critics Institute-Journal (BIRCI-Journal). P.0110.

Soerjono Soekanto. (2013). Sosiologi Suatu Pengantar, Jakarta: PT. RajaGrafindo Persada.

Sukanto. 2012. Sosiologi Suatu Pengantar, Jakarta: Rajawali Pers.

Teddy Tri Setio Berty. (2021) https://www.liputan6.com/global/read/4583268/kuotahanya-60-ribu-calon-haji-di-arab-saudi-yang-daftar-tembus-450-ribu, diakses pada: 20 Juni.

Vendy Yhulia Susanto. (2021). https://newssetup.kontan.co.id/news/pemerintah-batalkanpemberangkatan-haji-tahun-2021-ini-pertimbangannya?page=all, diakses pada: 20 Juni. 